\title{
Strategi Peningkatan Kinerja Nelayan dalam Rantai Pasok Ikan Layur melalui Pengembangan Modal Insani di Pelabuhanratu
}

\author{
Strategy of Increasing Fisherman Performance in Layur Lish Supply Chain through Develop \\ Human Capital at Pelabuhanratu
}

Herlina Retnowati ${ }^{{ }^{*}}$, Anggraini Sukmawati ${ }^{2}$ dan Tri Wiji Nurani ${ }^{3}$

Program Diploma Institut Pertanian Bogor

${ }^{2}$ Departemen Manajemen, Fakultas Ekonomi dan Manajemen Institut Pertanian Bogor

Jl. Kamper Kampus IPB Darmaga, Bogor 16680

${ }^{3}$ Departemen Pemanfaatan Sumberdaya Perikanan, Fakultas Perikanan dan Ilmu Kelautan

Institut Pertanian Bogor

Jl. Agatis, Kampus IPB Darmaga, Bogor 16680

\begin{abstract}
ABSTRAK
Penurunan ekspor ikan layur di Pelabuhanratu akar penyebab masalah adalah SDM/modal insani, masalah kinerja dan masalah rantai pasok. Studi ini bertujuan merumuskan strategi peningkatan kinerja nelayan dalam rantai pasok produk ikan layur melalui pengembangan modal insani. Strategi peningkatan kinerja nelayan didasarkan kegiatan observasi, wawancara mendalam dengan interview terhadap pihak-pihak terkait dan dianalisis dengan diagram tulang ikan (fishbone) untuk mengidentifikasi permasalahan yang terjadi di nelayan yang terkait penurunan ekspor ikan layur dan untuk strateginya digunakan analytical hierarchy process (AHP) untuk mendapatkan strategi yang tepat bagi nelayan. Berdasarkan hasil analisis yang dilakukan terhadap strategi kebijakan, didapatkan bahwa strategi penambahan pelatihan yang disesuaikan dengan kebutuhan diharapkan dapat meningkatkan kinerja nelayan, yang nantinya meningkatkan kesejahteraannya.
\end{abstract}

Kata kunci: diagram tulang ikan, kinerja, modal insani, rantai pasok, strategi

\section{ABSTRACT}

The decrease layur fish export in Pelabuhanratu. The roof of the problems are human resources or human capital, performance and supply chain problems. The purpose of this study is formulating the strategy of increasing fisherman performance strategy in ribbon fish supply chain through develop human capital. The increase of fisherman performance is got from the observe activity depth interview with the people who are related to and fishbone chart analized to identify problems which happened in fisherman that cause decreasing fish export and analytical hierarchy process (AHP) is used for the strategy to get a strategy which is suitanable with the fisherman. From the analyze result that we have done with strategy wisdom we are got is increasing training strategy which is adapted with the requirements we hope that it can increase fisherman performance, we hope that the welfare of fisherman will increase.

Key words: fishbone, human capital, performance, strategy, supply chain

\footnotetext{
*) Korespondensi:

Program Diploma IPB. Jl. Kumbang No 14 Cilibende Bogor Tengah 16151 Telp (0251) 8329101 Faks (0251) 8329101

e-mail: herlinaretnowati@yahoo.co.id
} 


\section{PENDAHULUAN}

Penurunan ekspor produk ikan layur di Pelabuhanratu memiliki kompleksitas masalah yang saling berkaitan antara rantai pasok, sumber daya dan modal insani, serta hal ini memerlukan suatu tindakan nyata yang mampu menyelesaikan masalah tersebut. Menurut Solihin (2003) menurunnya potensi sumber daya produk ikan layur diakibatkan oleh pengelolaan yang tidak memperhatikan kelestarian, belum memadainya sarana dan prasarana, SDM yang kurang paham dalam menangani produk tersebut, sampai dengan kebijakan perikanan yang masih belum mampu meningkatkan taraf kesejahteraan nelayan secara umum merupakan berbagai permasalahan yang ada di nelayan.

Produk perikanan yang dihasilkan memiliki karakteristik mudah busuk dan bersifat musiman, sehingga untuk sampai ke konsumen diperlukan suatu sistem manajemen rantai pasok yang baik dan memadai. Menurut Marimin (2010), manajemen rantai pasok adalah proses produksi secara keseluruhan dari kegiatan pengolahan, distribusi pemasaran, hingga produk yang diinginkan sampai ke tangan konsumen. Menurut Siagian (2005), manajemen rantai pasok merupakan pendekatan untuk pengelolaan, persediaan dan distribusi secara terintegrasi antara pemasok, produsen, distributor, dan pengecer untuk meminimalisasi biaya sistem secara keseluruhan.

Rantai pasok produk perikanan dalam prosesnya melibatkan beberapa pemain, diantaranya nelayan, pengumpul, pengusaha dan eksportir. Dalam jaringan rantai pasok produk perikanan terdiri dari lebih dari satu rantai pasok dan lebih dari satu proses bisnis yang dapat diidentifikasikan. SDM yang memadai diperlukan dalam mengelola rantai pasok ini, permasalahan utama saat ini adalah nelayan ikan layur belum paham benar bagaimana menangani ikan dengan baik, agar ikan tetap segar dan mutu ikan tetap terjaga. Menurut Parung (2008), peran modal insani dalam kerjasama bisnis untuk organisasi yang berbasis teknologi sangat dominan terhadap peran sumber daya fisik dan financial. Menurut Fisher et al (1993), fungsi SDM harus unggul sehingga dapat memberikan kontribusi optimal.

Keunggulan yang dimiliki Pelabuhanratu dalam memenuhi konsumsi produk ikan layur merupakan nilai tambah bagi organisasi sehingga diperlukan sistem manajemen sumber daya terintegrasi. Menurut Baron \& Michael (2013) manusia sebagai modal insani dapat termotivasi dapat berkinerja dengan lebih baik sesuai dengan pengetahuan, keterampilan dan kompetensi yang dimiliki-nya. Menurut Hsu (2006), modal manusia memiliki efek tidak langsung pada efektivitas organisasi melalui jalur pengetahuan dimana kemampuan memiliki efek tidak langsung pada efektivitas organisasi yang memberi pengaruh positif terhadap organisasi keunggulan kompetitif.

Kinerja nelayan dapat meningkat, apabila mendapat dukungan dari pemerintah didalam pemberdayaan masyarakatnya, sehingga diharapkan dengan meningkatnya kinerja nelayan, maka kesejahteraan nelayan meningkat pula. Kebijakan dan implementasi program pembangunan untuk masyarakat di kawasan pesisir hingga saat ini masih belum optimal dalam memutus mata rantai belenggu kemiskinan dan peningkatan kesejahteraan (Kusnadi, 2009).

Kinerja adalah bagaimana melakukan, menjalankan dan melaksanakan kewajiban dan tanggung jawab yang diharapkan oleh organisasi. Manajemen kinerja adalah proses komunikasi yang berlangsung terus menerus, yang dilaksanakan berdasarkan kemitraan antara seorang karyawan dengan pengawas langsungnya (Bacal, 2002). Hasil analisis menunjukkan bahwa manusia merupakan modal, meliputi peubah pendidikan yang dapat digunakan untuk pembangunan ekono-mi nasional secara nyata dan lebih baik, serta hal ini berimplikasi terhadap pengembangan SDM (Verkhohlyad, 2008).

Gambaran umum yang terjadi dilapang-an terkait masalah kompetensi nelayan yang didalamnya terkandung unsur keterampilan, kemampuan dan pengetahuan yang dimiliki oleh nelayan adalah merupakan suatu pembelajaran yang sudah turun menurun, maka diperlukan suatu strategi guna meningkatkan kapabilitas nelayan dalam kinerjanya. Menurut Gana (2011), masalah ini menjadi penting karena pada tingkatan tertentu, kemampuan yang kurang tidak dapat dikompensasikan dengan tingginya motivasi atau sebaliknya dan keduanya merupakan komponen penting dalam kinerja. Analisis yang digunakan diagram tulang ikan (fishbone) untuk mengidentifikasi akar penyebab masalah dan Analytical Hierarchy Process (AHP) untuk menentukan strategi tepat dalam meningkatkan kinerja nelayan.

Berdasarkan latar belakang tersebut perlu dirumuskan strategi apa yang sebaiknya dilakukan untuk dapat meningkatkan penguatan 
kapabilitas kinerja nelayan dalam rantai pasok ikan layur. Strategi yang dirumuskan berdasarkan permasalahan-permasalahan yang terjadi dengan cara menganalisis dan mengidentifikasi akar penyebab masalah dari turunnya ekspor ikan layur. Hasil dari rumusan strategi tersebut nantinya dapat dijadikan sebagai rekomendasi bagi para pemegang kebijakan dalam penentuan program kebijakan apa yang sebaiknya dilakukan guna meningkatkan kinerja nelayan.

\section{METODOLOGI}

Penelitian dilakukan di Pelabuhanratu, Kabupaten Sukabumi, Jawa Barat. Penelitian lapang mulai dilakukan pada bulan Februari 2014 hingga Mei 2014. Data yang dibutuhkan berupa data primer dan sekunder. Data sekunder diperoleh dari dokumen, literatur, jurnal ilmiah, laporan kajian terdahulu yang relevan, serta dari berbagai sumber dari instansi terkait dan pihakpihak yang relevan. Data primer diperoleh melalui observasi dan wawancara langsung kepada 5 pakar yang dianggap paling mengetahui tentang daerah penelitian yaitu kepala Dinas Kelautan dan Perikanan, Kepala Pelabuhan, Penyuluh, Akademisi, Pengusaha. Wawancara juga dilakukan terhadap nelayan dan kelompok serta pihak-pihak terkait. Metode penarikan contoh berdasarkan pendekatan teknik survei, dimana pengumpulan informasi dan pengetahuan dari responden menggunakan metode purposive sampling (pengambilan contoh yang diarahkan). Diagram tulang ikan (fishbone) digunakan untuk menganalisis akar penyebab masalah dari rendahnya kinerja nelayan di Pelabuhanratu dan dibatasi pada nelayan ikan layur. Analisis kinerja nelayan dibatasi pada produktivitas, profitabilitas dan inovasinya, Analisis rantai pasok produk ikan layur dibatasi pada aspek cara penanganannya mulai dari penangkapan, pengelolaan dan penyimpanan. AHP digunakan untuk merumuskan strategi peningkatanan kinerja nelayan dibatasi pada analisis peran dan fungsi dari lima sektor kelembagaan, yaitu Kepala Dinas Kelautan dan Perikanan Pelabuhanratu, Kepala Pelabuhan Perikanan, Penyuluh, akademisi, dan pengusaha.

\section{HASIL DAN PEMBAHASAN}

Struktur distribusi rantai pasok produk ikan layur pada umumnya memiliki konsep karakteristik yang sama dengan produk perikanan lainnya. Konsep rantai pasok merupakan suatu sistem tempat organisasi menyalurkan barang produksi dan jasa kepada pelanggan dan merupakan konsep baru dalam memandang persoalan logistik dalam suatu perusahaan Lena (2008). Aliran saluran distribusi rantai pasok ikan layur memiliki tiga pola struktur aliran yang selama ini diterapkan di Pelabuhanratu (Gambar 1).

Aliran distribusi produk ikan layur pada model rantai pasok pada Gambar 1 dibagi menjadi beberapa rantai, sebagai berikut:

1) Struktur Rantai 1

Nelayan $\rightarrow$ Pengumpul/bakul $\rightarrow$ Konsumen lokal.

Nelayan menjual barangnya melalui pengumpul atau bakul kepada konsumen lokal di pasar tradisional

2) Struktur Rantai 2

Nelayan $\rightarrow$ ketua kelompok/pengkoordinir $\rightarrow$ Perusahaan Eksporir $\rightarrow$ Pasar Luar Negeri/ konsumen.

Ketua kelompok ikan layur yang ada di Pelabuhanratu menjalin kerjasama dengan eksporir, yaitu PT AGB. Perusahaan ini memasarkan ikan layur ke Korea dan China. Ikan layur ini sebelum di ekspor ke luar negeri dikemas dahulu sesuai dengan besaran ukuran. Para ketua kelompok disisni hanya sebagai pengkoordinir dalam mengumpulkan hasil tangkapan.

3) Struktur Rantai 3

Nelayan $\rightarrow$ pengumpul/bakul $\rightarrow$ Perusahaan Eksporir $\rightarrow$ Pasar Luar Negeri

Para bakul disini menjalin kerjasama dengan perusahaan eksportir dalam memasarkan ikannya. Para bakul disini adalah sebagai pengumpul hasil produksi dan yang menjadi penego (penawar) harga dengan nelayan dan perusahaan.

Berdasarkan Gambar 1 maka saluran yang paling efektif adalah saluran ketiga karena langsung kepada konsumen akhir.

\section{Identifikasi Masalah Turunnya Ekspor Produk Ikan Layur di Pelabuhanratu}

Trend ekspor ikan layur di Pelabuhan-ratu selama kurun waktu lima tahun terakhir (20092013) menunjukan kecenderungan yang menurun, akar penyebab masalah dari penurunan ini perlu dilihat baik dari SDM Nelayan, kinerja dan rantai pasok. Akar penyebab masalah yang telah di identifikasi dapat di lihat pada Gambar 2. 


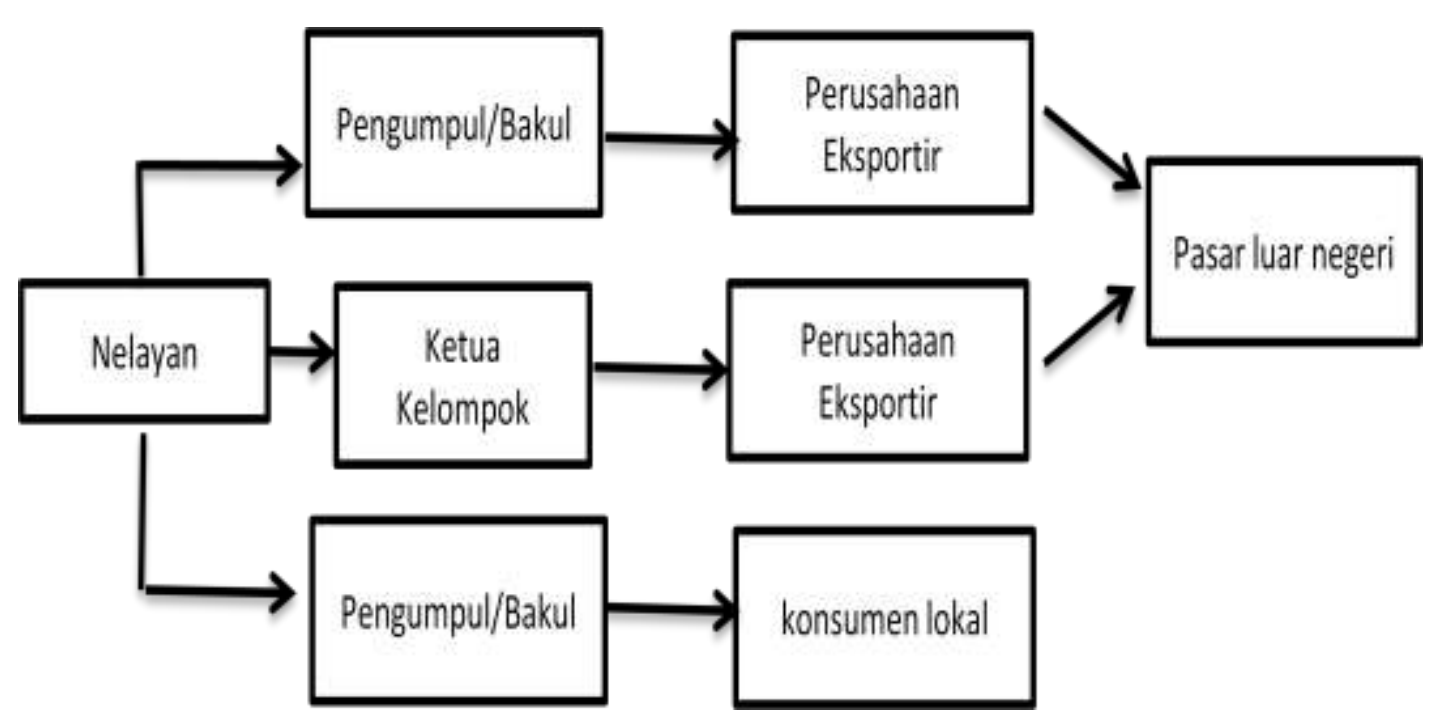

Gambar 1. Model distribusi produk ikan layur di Pelabuhanratu

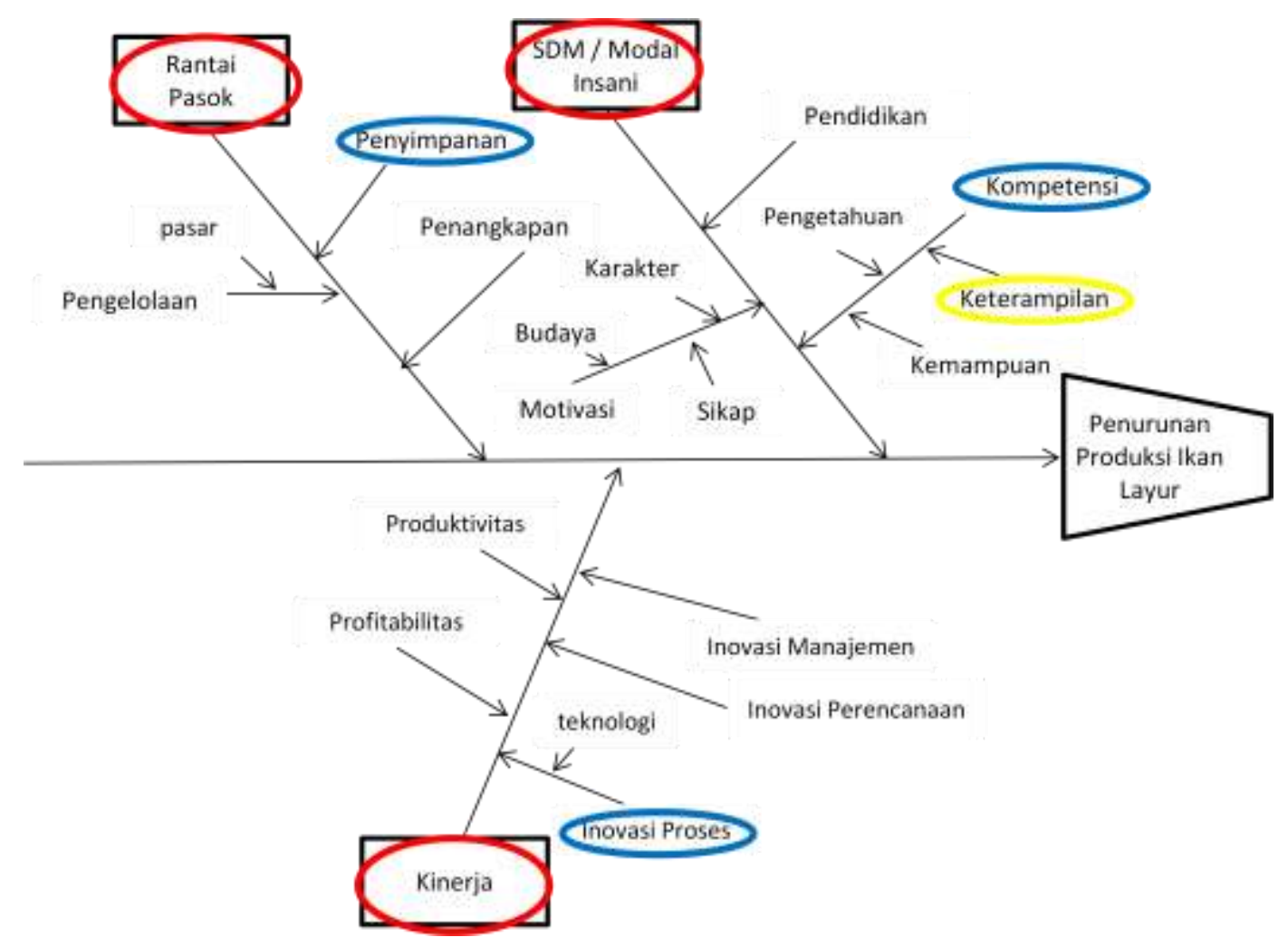

Gambar 2. Identifikasi penurunan produksi ikan layur

Akar penyebab masalah yang terkait dengan SDM nelayan adalah masalah pendidikan dimana rataan tingkat pendidikan nelayan adalah SD dengan presentase $73,28 \%$, dan hal ini tentunya menjadi hal yang sulit untuk ditingkatkan. Masalah motivasi, dalam motivasi terkait masalah budaya, karakter, sikap dari nelayan yang cenderung hidupnya santai, senang berfoya-foya dan bersifat konsumtif, semua ini menjadi karakter dari nelayan yang sulit sekali untuk dirubah. Masalah kompetensi, didalam kompetensi terkandung unsur keterampilan, pengetahuan dan kemampuan; semua ini mereka dapatkan dari proses pembelajaran yang bersifat turun temurun sebagai nelayan sehingga kompetensi ini masih dapat ditingkatkan untuk lebih baik. Menurut Soesarsono (2002) SDM dapat dilihat dari faktor kompetensi selain faktor-faktor lainnya seperti agama, pendidikan dan kecerdasan. 
Dilihat dari rantai pasok dalam memenuhi standar ekspor yang dibutuhkan, nelayan masih belum paham benar cara menangani ikan layur dengan baik sesuai dengan standar ekspor yang dibutuhkan mulai dari cara penangkapan, pengelolaan dan penyimpanannya. Sehingga seringkali ikan layur yang dihasilkan menjadi kurang baik mutunya.

Terkait masalah kinerja nelayan yang didalamnya mengandung masalah produktivitas, profitabilitas dan inovasi mulai dari inovasi proses, manajemen dan inovasi perencanaan. Untuk memenuhi standar ekspor, maka nelayan dituntut untuk lebih terampil didalam mengelola ikan layur terutama didalam hal inovasi prosesnya agar mutunya tetap terjaga dengan baik dan ini terkait dengan masalah teknologinya.

Berdasarkan hasil identifikasi masalah yang telah dilakukan terlihat bahwa akar penyebab masalah turunnya ekspor ikan layur di Pelabuhanratu yang paling dominan didalam rantai pasok adalah masalah penyimpanan, di SDM adalah masalah kompetensi terkait keterampilannya dan di kinerja adalah masalah inovasi proses. Hal ini diakibatkan oleh karena nelayan ikan layur adalah nelayan yang masih tradisional sehingga baik di teknologi, cara penyimpanan dan cara memprosesnya masih sangat tradisional. Harapan kedepannya bahwa nelayan ikan layur dapat lebih terampil didalam memenuhi kebutuhan akan standar ekspor ikan layur yang dibutuhkan oleh eksportir.

\section{Strategi Peningkatan Kinerja Nelayan dalam Rantai Pasok Ikan Layur melalui Pengembangan Modal Insani di Pelabuhanratu}

Mengacu kepada hasil identifikasi masalah (Gambar 2) yang terjadi di Pelabuhanratu, dalam menganalisis strategi peningkatan kinerja nelayan yang dianggap paling sesuai perlu di susun suatu bagan struktur yang dapat dijadikan acuan didalam pengambilan keputusan yang terbaik. Analisis Hierarkhi Proses (AHP) yang dilakukan didalam strategi peningkatan kinerja nelayan dibagi dalam 5 kategori kunci yang paling berperan dalam yaitu (1) Kepala Dinas Kelautan \& Perikanan; (2) Kepala Bandar Pelabuhanratu; (3) Penyuluh Nelayan; (4) Pengusaha Ikan Layur yang ada di Pelabuhanratu, dan (5) Pakar Akademisi.

Suatu strategi didalam penentuannya perlu melihat aspek modal insani yaitu mengenai keterampilan, kompetensi dan pengetahuan nelayan; dan dala kinerjanya adalah mengenai produktivitas, profitabilitas, inovasi baik inovasi manajemen, inovasi perencanaan dan inovasi prosess yang didalamnya terkandung masalah teknologinya dan yang terakhir aspek rantai pasoknya terkait masalah penangkapan, penyimpanan dan pengelolaan dimana pengelolaan disini terkandung juga masalah dalam pengelolaan pasarnya.

Alternatif strategi yang di rekomendasikan, yaitu (1) Peningkatan sistem pengelolaan \& pengembangan SDM; (2) Kebijakan \& program yang disesuaikan dengan kebutuhan; (3) Merubah etos kerja nelayan; dan (4) Penambahan pelatihan bagi nelayan.

Analisis Hierarkhi Proses (AHP) merupakan kerangka analisis untuk pengambilan suatu keputusan secara efektif untuk permasa-lahan yang kompleks, dengan menyederhana-kan dan mempercepat pengambilan keputusan (Nurani, 2003). Analisis keputusan ini merupakan hasil analisis pemilihan strategi yang paling tepat bagi nelayan ikan layur di Pelabuhanratu, setelah dilakukan analisis dengan menggunakan AHP maka disusunlah suatu struktur hierarkhi dengan mengkombinasikan peubah yang menjadi prioritas pada setiap hirarki dengan cara menata bagian atau peubah dalam susunan hierarkhi dengan memberi pertimbangan numerik pada pertimbangan subjektif tentang relatif pentingnya peubah dan mensintesis berbagai pertimbangan untuk menetapkan peubah yang memiliki prioritas tertinggi.

Hirarki yang disusun terdiri dari enam tingkat. Tingkat pertama adalah tujuan, yaitu strategi peningkatan kinerja nelayan pelabuhanratu. Tingkat kedua adalah aktor yang terdiri atas Kepala Dinas Kelautan dan Perikanan Pelabuhanratu, Kepala Pelabuhan Perikanan, akademisi, pengusaha ikan layur, dan penyuluh. Tingkat ketiga adalah faktor yang terdiri atas modal insani, kinerja, dan rantai pasok. Tingkat keempat adalah sub faktor. Sub faktor dari faktor modal insani terdiri atas pengetahuan, kompetensi, dan keterampilan. Sub faktor dari faktor kinerja terdiri atas produktivitas, profitabilitas, inovasi manajemen, inovasi perencanaan, dan inovasi proses. Sub faktor dari faktor rantai pasok terdiri atas pengelolaan, penyimpanan, dan penangkapan. Kemudian tingkat keenam adalah alternatif yang terdiri atas meningkatkan kompetensi pengelolaan dan pengembangan SDM, kebijakan dan program yang disesuaikan dengan kebutuhan, merubah etos kerja nelayan, dan 
penambahan pelatihan pada nelayan. AHP dilakukan menggunakan program Expert Choice 11, dan diperoleh hasil yang dirangkum dalam prioritas lokal dan prioritas global.

Hasil analisis terhadap faktor aktor yang paling dominan dalam penentuan strategi peningkatan kinerja nelayan berdasarkan jawaban dari penyuluh lapangan yang mengerti betul dengan areal penelitian adalah faktor kepala Dinas Kelautan dan Perikanan dengan persentase 39,8\%, Penyuluh 26,6\%, Akademisi 17,7\%, Kepala Pelabuhan 9,3\% dan Pengusaha 6,5\%. Hirarki faktor yang paling dominan dalam penentuan peningkatan kinerja nelayan berdasarkan jawaban dari responden ahli adalah faktor rantai pasok dengan persentase $70,76 \%$, disusul faktor modal insani $21,94 \%$, serta faktor kinerja $7,12 \%$.

Sub faktor yang paling dominan yang ada dalam satu faktor berdasarkan faktor modal insani, adalah keterampilan (41,02\%). Berdasarkan faktor kinerja, sub faktor yang paling dominan adalah inovasi proses (30,82\%). Berdasarkan faktor rantai pasok, sub faktor yang paling dominan adalah penyimpanan $(66,06 \%)$.

Prioritas lokal merupakan prioritas elemenelemen dalam satu level dengan hanya mempertimbangkan satu faktor saja. Untuk itu prioritas lokal ditentukan dengan memperhatikan sub faktor dari masing-masing faktor diatas. Peubah yang menjadi prioritas dalam modal insani, strategi yang terbaik yang seharusnya dilakukan agar kinerja nelayan menjadi lebih meningkat dilihat dari sub kriteria (1) pengetahuannya adalah strategi penambahan pelatihan bagi nelayan dengan nilai 0.373 atau $37,26 \%$; (2) kompetensi, peubah yang menjadi prioritas dalam menentukan strategi yang terbaik yang seharusnya dilakukan agar kinerja nelayan menjadi lebih meningkat dilihat dari sub kriteria kompetensinya adalah strategi penambahan pelatihan bagi nelayan dengan nilai 0,559 atau $55.9 \%$; (3) Keterampilan, peubah yang menjadi prioritas dalam menentukan strategi yang terbaik yang seharusnya dilakukan agar kinerja nelayan menjadi lebih meningkat dilihat dari sub kriteria keterampilannya adalah strategi penambahan pelatihan bagi nelayan dengan nilai 0,551 atau $55,06 \%$.

Hierarkhi ketiga dari faktor penentu dalam menentukan strategi apa yang sebaiknya dilakukan agar kinerja nelayan lebih meningkat dilihat dari kinerja terkait (1) produktivitasnya. Peubah yang menjadi prioritas dalam menentukan strategi yang terbaik yang seharusnya dilakukan agar kinerja nelayan menjadi lebih meningkat dilihat dari sub criteria produktivitasnya adalah strategi penambahan pelatihan bagi nelayan dengan nilai 0,431 atau $43,14 \%$. (2) Profitabilitasnya, peubah yang menjadi prioritas dalam menentukan strategi yang terbaik yang seharusnya dilakukan agar kinerja nelayan menjadi lebih meningkat dilihat dari sub kriteria profitabilitasnya adalah strategi penambahan pelatihan bagi nelayan dengan nilai 0,388 atau $38,76 \%$. (3) Inovasi manajemen, peubah yang menjadi prioritas dalam menentukan strategi yang terbaik yang seharusnya dilakukan agar kinerja nelayan menjadi lebih meningkat dilihat dari sub kriteria inovasi manajemennya adalah strategi penambahan pelatihan bagi nelayan dengan nilai 0,501 atau $50,1 \%$. (4) Inovasi perencanaan, peubah yang menjadi prioritas dalam menentukan strategi terbaik yang seharusnya dilakukan agar kinerja nelayan menjadi lebih meningkat dilihat dari sub kriteria inovasi perencanaannya adalah strategi penambahan pelatihan bagi nelayan dengan nilai 0.451 atau $45,08 \%$. (5) Inovasi proses, peubah yang menjadi prioritas dalam menentukan strategi yang terbaik yang seharusnya dilakukan agar kinerja nelayan menjadi lebih meningkat dilihat dari sub kriteria inovasi prosesnya adalah strategi penambahan pelatihan bagi nelayan dengan nilai 0,471 atau $47,12 \%$.

Hierarkhi ketiga dari faktor penentu dalam menentukan strategi apa yang sebaiknya dilakukan agar kinerja nelayan lebih meningkat dilihat dari rantai pasok terkait masalah (1) Pengelolaan, peubah yang menjadi prioritas dalam menentukan strategi yang terbaik yang seharusnya dilakukan agar kinerja nelayan menjadi lebih meningkat dilihat dari sub kriteria pengelolaannya adalah strategi penambahan pelatihan bagi nelayan dengan nilai 0,495 atau $49,5 \%$. (2) Penyimpanan, peubah yang menjadi prioritas dalam menentukan strategi yang terbaik yang seharusnya dilakukan agar kinerja nelayan menjadi lebih meningkat dilihat dari sub kriteria penyimpanan adalah strategi penambahan pelatihan bagi nelayan dengan nilai 0,467 atau $46,7 \%$. (3) Penangkapan, peubah yang menjadi prioritas dalam menentukan strategi yang terbaik yang seharusnya dilakukan agar kinerja nelayan menjadi lebih meningkat dilihat dari sub kriteria penangkapan adalah strategi penambahan pelatihan bagi nelayan dengan nilai 0,555 atau $55,46 \%$.

Prioritas global merupakan prioritas yang memperhatikan seluruh kriteria, kemudian hasil 
yang diperoleh dari prioritas global ini digunakan sebagai alternatif strategi peningkatan kinerja nelayan di pelabuhanratu. Peubah yang menjadi prioritas secara menyeluruh dalam menentukan strategi yang terbaik yang seharusnya dilakukan agar kinerja nelayan menjadi lebih meningkat adalah penambahan pelatihan pada nelayan di pelabuhanratu dengan persentase $48,28 \%$. Selanjutnya yang menjadi prioritas kedua adalah merubah etos kerja $(25,38 \%)$, dan yang menjadi prioritas ketiga adalah meningkatkan kompetensi pengelolaan dan pengembangan SDM $(15,5 \%)$, serta yang menjadi prioritas keempat adalah kebijakan dan program (10.8\%).

Hasil analisis yang diperoleh menunjukkan bahwa peningkatan kinerja nelayan didalam rantai pasok ikan layur melalui pengembangan modal insani, memerlukan suatu kebijakan terkait dengan program pelatihan yang memiliki kekhususan yang diperlukan oleh nelayan. Jenis pelatihan yang bersifat fleksibel peruntukannya bukan saja untuk nelayan itu sendiri, akan tetapi bagi keluarganya, dimana strategi peningkatan kinerja didalam rantai pasok yang fleksibel perlu ditetapkan untuk memberikan kemampuan manajer untuk menetapkan prioritas yang jelas dalam investasi dan pengembangan (Fantazi, 2007). Dalam pemberdayaan masyarakatnya, proses pengambilan keputusan dilakukan oleh orang-orang yang memiliki kompetensi terhadap pelaksanaan keputusan (McArdle, 1989).

Berdasarkan hasil analisis yang telah dilakukan bahwa faktor aktor yang paling berperan dalam penentuan strategi peningkatan kinerja nelayan adalah Kepala Dinas Kelautan dan Perikanan dengan presentase 39,8\%. Faktor yang paling mempengaruhi adalah rantai pasok dengan presentase $70,8 \%$. Sub faktor dari faktor yang paling berpengaruh dalam modal insani adalah keterampilan dengan presentase $41,02 \%$; dalam kinerja adalah inovasi proses $30,8 \%$ dan didalam rantai pasok adalah penyimpanan $66,1 \%$. Alternatif yang paling sesuai adalah penambahan pelatihan yang disesuaikan dengan kebutuhan $48,3 \%$.

\section{IMPLIKASI MANAJERIAL}

Implikasi manajerial yang dapat direkomendasikan berdasarkan hasil analisis, dapat dijadikan dasar bagi pemerintah (Kepala Dinas Kelautan \& Perikanan) dalam membuat kebijakan program pelatihan. Program pelatihan ini dapat disesuaikan dengan kebutuhan nelayan ikan layur, saat ini pelatihan yang dutuhkan adalah bagaimana cara untuk memenuhi standar kualitas ekspor. Program pelatihan lain dapat juga diperuntukan bagi istri nelayan atau anak nelayan. Bentuk pelatihan tersebut antara lain bagaimana cara mengolah ikan agar tidak mudah busuk/ rusak, bagaimana mengolah ikan pada saat panen sehingga ikan tidak terbuang percuma. Menurut Karami (2004), unsur utama untuk mencapai kesuksesan diperlukan keterlibatan SDM dalam pengembangan dan dalam pelaksanaan strategi.

Peningkatan kinerja nelayan ekspor ikan layur di Pelabuhanratu banyak dipengaruhi oleh berbagai masalah yang melingkupinya, sehingga diperlukan suatu upaya terintegrasi dalam pengelolaan rantai pasok dan modal insaninya. Pengelolaan rantai pasok sangat berkaitan dengan produk ikan layur, produksi ikan layur di Pelabuhanratu dikhawatirkan lambat laun akan punah (Gambar 2). Perlu kebijakan dari pemerintah untuk mengatasi hal tersebut, terutama yang berkaitan dengan tata ruang kelautan dan program pelestarian sumber daya ikan layur. Edward (2001) menyatakan bahwa kurangnya pemantauan dari pemerintah dalam pengelolaan perikanan dalam skala kecil mengakibatkan penurunan stok sumber daya. Mengacu pernyataan Sipaheulut (2010) di tempat lain bahwa pembagian peran secara proposional dan profesional didalam pengelolaan sumber daya perikanan akan lebih efektif, efisien dan adil, sehingga diharapkan kesejahteraan nelayan akan meningkat dan kelestarian sumber daya perikanan dapat berlanjut.

Pemetaan peran didalam rantai pasok ikan layur, bila dilihat dari peran masing-masing pelaku terlihat bahwa aktivitas yang terbanyak ada pada nelayan dan kehidupan nelayan masih sangat tergantung kepada hasil laut (Utami, 2010) sementara nilai tambah terbanyak didapatkan oleh bakul. Perlu adanya suatu proses bisnis dalam pengelolaannya, artinya nelayan harus meningkatkan kompetensi dengan suatu pelatihan, agar peran bakul atau pengumpul dapat digantikan langsung kelompok dan nelayan agar nilai tambah yang didapatkan oleh nelayan dapat maksimal. Dukungan kepercayaan yang terbangun diantara anggota rantai pasok juga sangat penting guna kelancaran dalam aktivitasnya. Berdasarkan hasil analisis maka urutan skor tertinggi dari masing-masing kriteria dapat dilihat pada Tabel 1 dan Gambar 3. 


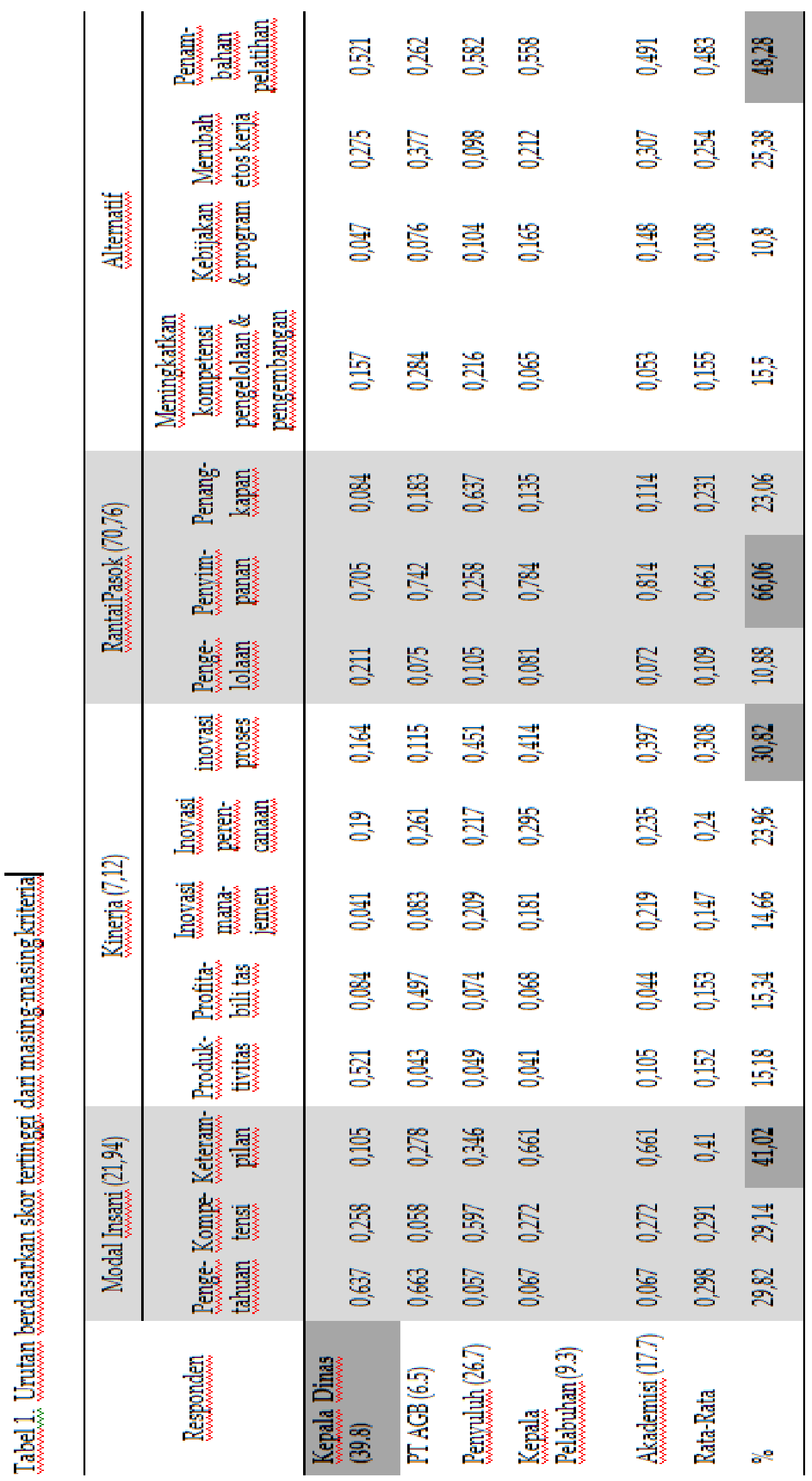




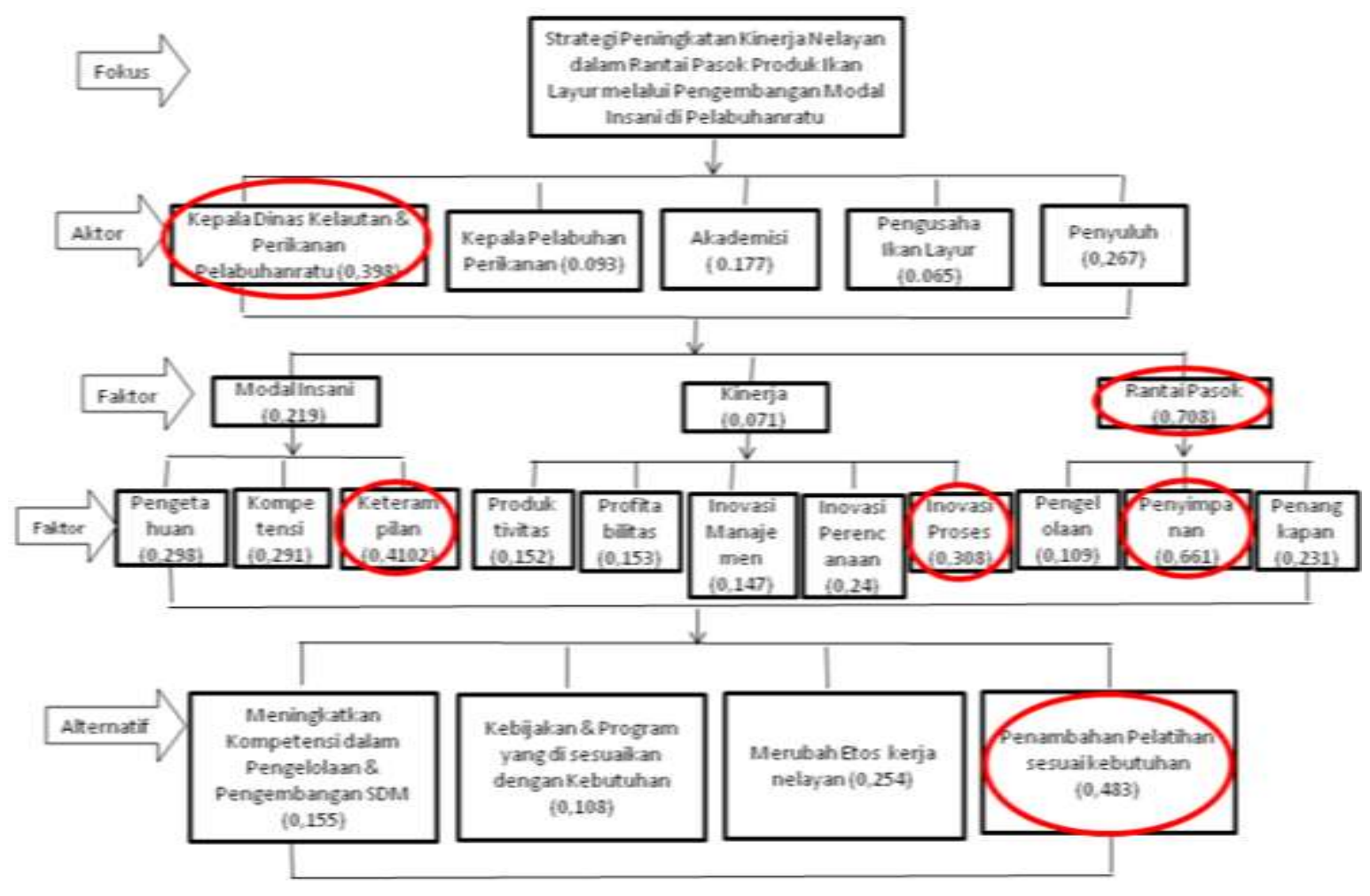

Gambar 3. Bagan struktur strategi peningkatan kinerja nelayan dalam rantai pasok produk ikan layur melalui pengembangan modal insani

\section{KESIMPULAN}

Permasalahan mendasar dalam penurunan ekspor ikan layur yang disebabkan oleh belum pahamnya nelayan didalam menangani ikan layur sehingga kinerjanya menjadi menurun adalah masalah keterampilan SDM, masalah penyimpanan didalam rantai pasoknya dan didalam inovasi proses. Alternatif strategi (1) meningkatkan sistem pengelolaan dan pengembangan SDM; (2) kebijakan dan program yang di sesuaikan dengan kebutuhan; (3) mengubah etos kerja nelayan dan (4) penambahan pelatihan sesuai kebutuhan. Berdasarkan hasil analisis didapatkan strategi yang paling sesuai dan paling dibutuhkan saat ini oleh nelayan ikan layur adalah strategi penambahan pelatihan menurut kebutuhan.

\section{DAFTAR PUSTAKA}

Bacal, R. 2002. Performance Management. Terjemahan Surya Dharma, Yanuar Irawan, Gramedia, Jakarta.

Baron, A dan A. Michael. 2013. Modal Insani Management. Konsep dan Implementasi. Terjemahan Lilian Juwono, Sonta Frisca, Jakarta PPM.
Fantazy, K. 2007. An Empirical Study of the Relationship Among Strategy, Flexibility, and Performance in the Supply Chain Context. ProQuest Disertation and Thesis.

Fisher, C.D., L.F. Schoenfeldt, \& James B. Shaw. (1993). Human Resource Management, 2th Ed, Houghton Mifflin Company.

Gana, A.B. 2011. The Effect of Motivation on Workers Perfromance (A case Study of Maiduguriflour Mill Ltd. Borno State, Nigeria). Continental J. Social Sciences, Willolud Journal 4(2), ISSN 2141-4265: 8-13.

Hsiu-Yueh (Sonya) Hsu. 2006. "Knowledge Management and Intellectual Capital". A Dissertation Submitted in Partial Fulfillment of the Requirements for the Doctoral of Philosophy Department of Management in the Graduate School Southern Illinois University Carbondale.

Karami, A., F. Analoui, \& J. Cusworth. 2004. Strategic Human Resources Management and Resource-Based Approach: The Evidence from the British Manufacturing Industry. Management Research News.

Kusnadi. 2009. Keberdayaan Nelayan dan Dinamika Ekonomi Pesisir. Pusat Penelitian Wilayah Pesisir dan Pulau-Pulau Kecil. 
Jember: Lembaga Penelitian Universitas Jember.

Lina, L. 2008. Supply Chain Management Teori dan Aplikasi. Alfabeta.

Mangkuprawira, S. 2004. Manajemen Sumber Daya Manusia Strategik. Ghalia Indonesia, Jakarta.

Marimin dan N. Magfiroh, 2010. Aplikasi Teknik Pengambilan Keputusan dalam Manajemen Rantai Pasok. IPB Press.

McArdle , J. 1989. Community Development Tolls of Trade. Community Quarterly Journal 16: 47-54.

Nurani, T. 2003. Proses Hierarki Analitik (Analytical Hierarchy Process) suatu Metoda untuk Analisis Kebijakan Pengelolaan Sumber Daya Perikanan. Konsep Pengembangan Sektor Perikanan dan Kelautan di Indonesia.
Parung, J. 2008. Jurnal Peran Modal Intelektual dalam Kerjasama Bisnis untuk Penciptaan Nilai Rantai Pasok.

Rekasiwi. 2014. Thesis Strategi Peningkatan Kinerja Usaha Kecil dan Menengah (UKM) Agro Kota Bogor melalui Modal Insani dan Modal Sosial. FEM IPB.

Sipahelut. 2010. Analisis Pemberdayaan Masyarakat Nelayan di Kecamatan Tobelo Kabupaten Halmahera Utara. Thesis FPIK IPB.

Solihin, I. 2003. Konsep Pengembangan Sektor Perikanan dan Kelautan di Indonesia. Departemen Pemanfaatan Sumber Daya Perikanan Fakultas Perikanan dan Ilmu Keluatan IPB.

Verkhohlyad, O. 2008. Disertasi "The Development of an Improved Modal insani Index for Assesing and Forecasting National Capacity and Development". 